UDC 612(091)(477)“18/19"

DOI: $10.24919 / 2519-058 x .16 .210908$

\title{
Volodymyr SHULHA
}

PhD hab. (History), Vice-Rector of Kharkiv National University of Internal Affairs, 27 L. Landau Avenue, Kharkiv, Ukraine, postal code 61080 (shulhavp@online.ua)

ORCID: http://orcid.org/0000-0001-9389-6691

ResearcherID: C-7262-2019 (http://www.researcherid.com/rid/C-7262-2019)

\section{Володимир ШУЛЬГА}

доктор історичних наук, проректор Харківського начіонального університету внутрішніх справ, проспект Л. Ландау, 27, м. Харків, Украӥна, індекс 61080 (shulhavp@online.иа)

Бібліографічний опис статті: Shulha, V. (2020). General physiology formation and development as a science in Ukraine in the XIXth - during the 30-ies of the XXth century. Skhidnoievropeiskyi Istorychnyi Visnyk [East European Historical Bulletin], 16, 36-49. doi: 10.24919/2519-058x.16.210908

\section{GENERAL PHYSIOLOGY FORMATION AND DEVELOPMENT AS A SCIENCE IN UKRAINE IN THE XIXth - DURING THE 30-ies OF THE XXth CENTURY}

\begin{abstract}
The purpose of the article is to highlight the General Physiology development main periods and tendencies in Ukraine, summarizing the regional research and educational centers' achievements, as well as making conclusions on individual scientists'achievements in the XIXth - the 30-ies of the XXth century on the world biological thought development background. The methodology of the research is based on the general scientific principles of objectivity, systematicity, complexity and scientificity. The author used the general scientific, interdisciplinary and special historical methods. The article is based on the factual material, archival documents that reveal basic physiological sciences and theories evolution, the organization of specialized departments and laboratories at higher educational institutions and research institutions of Ukraine. The scientific novelty of the article is that the author for the first time has demonstrated the regional scientific and educational centers'formation peculiarities, their personalized composition and contribution to the basics of a human and animal physiology development. The Conclusions. It was proved that the world biological thought development had a significant influence on the General Physiology development systematic research in the Ukrainian lands. Several periods of the Domestic Physiology scientific foundations formation and development have been singled out. The first Physiological Departments were established within the Natural Sciences and Medical Faculties of universities during 1805 - 1861. During 1861 - 1917 the Physiology Departments were organized at the veterinary and agricultural institutes. Numerous scientists have made a significant contribution to the physiological research deployment in Ukraine, for instance, B. F. Verigo, V. Ya. Danylevskyi, I. M. Syechenov, V. Yu. Chahovets, I. P. Shchelkov. The number of Physiology Departments at the universities and at the pedagogical, agricultural, veterinary, zootechnical institutes increased dramatically during the 1920-ies and 1930-ies. Furthermore, Physiology Independent Research Institutes and Physiological Departments at some institutions were created. The scientific directions, which were subject to the most detailed processing, were revealed, for instance, Nerve and Muscle Physiology, Electrophysiology and Biophysics, Comparative Physiology of Aging, Endocrinology and Physiology of Work. The decisive contribution to their development has been made by V. M. Arkhanhelskyi, V. M. Vasylevskyi, A. M. Vorobyov,
\end{abstract}


D. S. Voroncova, T. T. Huryeyeva, V. Ya. Danylevskyi, A. I. Yemchenko, E. M. Kogan, P. H. Kostyuk, H. P. Markelov, V. P. Prototypova, M. O. Rohovych, I. M. Sechenov, P. M. Syerkov, E. I. Synelnykov, Ya. P. Sklyarova, R. Yo. Feitelberg, G. W. J. Volborth, S. Yu. Yaroslava and others.

Key words: higher education, scientific research, Physiology, Medicine, labor protection, Biophysics, nervous system, Endocrinology, human.

\title{
СТАНОВЛЕННЯ І РОЗВИТОК ЗАГАЛЬНОЇ ФІЗІОЛОГІЇ ЯК НАУКИ НА ТЕРЕНАХ УКРАЇНИ В ХІХ - 30-х рp. ХХ ст.
}

\begin{abstract}
Анотація. Метою статті є висвітлення основних періодів $і$ тенденцій розвитку загальної фізіології в Україні XIX-30-х рр.. ХХ ст. на тлі розвитку світової біологічної думки. Методологія дослідження трунтується на загальнонаукових принципах об'єктивності, системності, комплексності та науковості. Автор використав загальнонаукові, міждисциплінарні та спеціальні історичні методи. Стаття базується на фактичному матеріалі, архівних документах, які розкривають еволюиію основних фізіологічних учень і теорій, організаџію спеціалізованих кафедр і лабораторій при закладах вищої освіти $і$ наукових установах Украйни. Наукова новизна статті полягає в тому, що автор уперше продемонстрував особливості становлення регіональних наукових і освітніх иентрів, їх персоніфікований склад та внесок у розроблення основ фізіології людини і тварин. Висновки. Доведено значний вплив розвитку світової біологічної думки на розгортання системних досліджень із загальної фізіології на украӥнських землях. Виділено кілька періодів становлення і розвитку наукових основ вітчизняної фізіології. Упродовж 1805 - 1861 рр. створюють периі фізіологічні кафедри у складі природничих і медичних факультетів університетів. У 1861 - 1917 рр. організовують кафедри фізіології при ветеринарних і сільськогосподарських інститутах. Доведено вагомий внесок у розгортання фізіологічних досліджень в Україні Б. Ф. Веріго, В. Я. Данилевського, І. М. Сєчєнова, В. Ю. Чаговия, І. П. Щелкова. У 20-30-ті рр. зростає кількість кафедр фізіології при університетах, педагогічних, сільськогосподарських, ветеринарних, зоотехнічних інститутах. Створюються самостійні науково-дослідні інститути фізіології і фізіологічні відділи при деяких установах. Виявлено наукові напрями, які підлягали найбільш детальному опраџюванню: фізіологія нервів і м'язів, електрофізіологія та біофізика, порівняльна і вікова фізіологія, ендокринологія і фізіологія прачі. Обтрунтовано вирішальний внесок у їх розроблення В. М. Архангельського, В. М. Василевського, А. М. Воробйова, Д. С. Ворониова, Т. Т. Гурєєва, В. Я. Данилевського, А. І. Смченка, Е. М. Кагана, П. Г. Костюка, Г. П. Маркелова, В. П. Прототипова, М. О. Роговича, І. М. Сєченова, П. М. Серкова, С. І. Синельникова, Я. П.Склярова, Р. Й. Файтельберга, Г. В. Фольборта, С. Ю. Ярослава та ін.
\end{abstract}

Ключові слова: вища освіта, наукові дослідження, фізіологія, медицина, охорона прачі, біофізика, нервова система, ендокринологія, людина.

The Problem Statement. Taking into consideration the new civilizational challenges conditions, a nation health level determines its future development, ability of spiritual and cultural growth. In addition, a human health is a crucial factor in the economic development, welfare growth and living standards of its citizens, socio-economic maturity, culture and prosperity of the state. In the context of the omnipresent economic crisis in Ukraine, material and financial resources reduction, socio-political conflict, climate change, man-made cataclysms, studying the human life physiological patterns issue as a basis for the health care is gaining special relevance.

According to world development, which convincingly proves that the purposeful influence on the physiological processes occurring in the human body, allows to increase its vital functions and productivity, to model its health and longevity. Hence, there is an urgent need to study the general physiology history of formation and development issues as a science in the Ukrainian lands in the XIXth - during the 30-ies of the XXth century. Diverse 
discoveries and achievements in this scientific field are an important factor in studying the regional aspect of the history of science and technology, the research centers formation and development, specialized educational institutions, the nation's scientific potential formation.

The Analysis of Sources and Recent Researches. Modern researchers managed to reveal the General Physiology formation and development main tendencies in the Russian Empire, which included the Ukrainian lands (Samoilov, 2005; Sorokina, 2012). Moreover, the researchers studied the main milestones of the organization of higher educational institutions and research institutions, on the basis of which the General Physiology issues were developed and highlighted, in particular the achievements of Kharkiv and Odesa universities, St. Volodymyr's University (Kyiv), Kyiv and Kharkiv Medical Institutes (Gholovko, Ruban \& Kandyba, 2006; Goncharuk, 1991; Stupak, 2002; Shvalb, Ghlybycjka \& Stavnycjka, 2007). The physiology of farm animals formation and development history was reproduced, which was developed mainly on the basis of Kharkiv Veterinary Institute (Borodai, 2012). There were diverse works on the General Physiology dedicated to the renowned researchers, in particular B. F. Veriho, V. Ya. Danylevskyi (Vasilev, 2010; Lisovyi, 2010; Marynzha, 2011; Smyntyna, 2005; Cyghanenko, Kryvonosov \& Kravchun, 2005). The researchers on the history of science also paid attention to the General Physiology scientific schools, as a result, the thorough study was conducted on Professor I. P. Pavlov's scientific school activities (Zagrina, 2009). However, the following issues were not covered: the achievements' influence and foreign scientists' discoveries on the development of research practices in human and animal physiology in Ukraine, taking into account the regional aspect and personalized contribution to the development of its basic students and theories, educational and methodical literature.

The purpose of the article is to highlight the General Physiology development main periods and tendencies in Ukraine, summarizing the regional research and educational centers' achievements, as well as making conclusions on individual scientists' achievements in the XIXth - the 30-ies of the XXth century on the world biological thought development background.

The Statement of the Basic Material. It is well known that General Physiology singled out as a science due to the research conducted by the English scientist W. Harvey, who in the $1628^{\text {th }}$ formalized the position of the large and small circles of blood. There were numerous researchers, whose works were the lion's share concerning the General Physiology issue. J. Borelli, the Italian scientist used the laws of mechanics as a basis for discovering the animals respiratory system mechanism at the end of the XVII century. The English researcher S. Hales established the norm of blood pressure, the French scientist R. Reaumur and the Italian naturalist L. Spallanzani revealed the chemical laws of digestion. The French researcher A. Lavoisier described the mechanism of oxidation, and the Italian scientist L. Galvani discovered a bioelectrical phenomenon in the human body. In addition, the most significant achievements of the first half of the XVIIth century were the discovery conducted by R. Descartes and in the XVIIIth century by J. Prohaska on the reflex principle, which explained the activity of the organism as a result of external stimuli occurring through the central nervous system (Kogan, 2004, pp. 44-48).

The study on the physiological processes of neuromuscular tissue was important for the design of general physiology as a science. German scientists E. Dubois-Raymond and $\mathrm{K}$. Ludwig designed the first induction device, a kymograph, a float manometer for recording the blood pressure, a blood clock to determine the speed of blood circulation, and others. The 
French physiologist E. Murray developed a device for recording the movement of the chest, and the Italian researcher A. Mosso - equipment for studying the blood supply to organs and fatigue, a weighing table to establish the redistribution of blood. The studies initiated by A. Volta and L. Galvani on electrical phenomena in the body, were continued by DuboisRaymond, L. Herman (Samoilov, 2005, pp. 24-28).

The Physiology scientific foundations establishment in the Russian Empire took place in the first half of the XVIIIth century after the organization of the first educational institution the Anatomy and Physiology Department at the St. Petersburg Academy of Sciences, headed by D. Bernoulli. In addition, Moscow University Medical Faculty, where S. H. Zabelin started its teaching process, played an important role in the design of Physiology as an independent science. An independent department of Physiology at the university, headed by M. I. Skiadan, was opened in 1776. The first textbook on Physiology was prepared in 1836 by A. M. Filomafitskyi, a professor at Moscow University. The first thesis on Animal Physiology was written in 1794 by F. I. Barsuk-Moiseyev and was dedicated to the study of the respiratory mechanisms. It should be mentioned that the organic Chemistry achievements, the conservation law and energy conversion discovery, the cellular structure of the organism, the creation of the theory of the evolutionary development of the organic world, and so on, were vital for the National Physiology formation. The studies conducted by M. V. Lomonosov, who gave much credit to Chemistry in the physiological processes knowledge, should be especially highlighted (Kogan, 2004, pp. 124-128).

I. M. Sechenov, the Russian scientist was the first, who registered the electrical phenomena in the human central nervous system. In 1862 the scientist discovered the inhibition process in the central nervous system. O. O. Ukhtomskyi, Sechov's student developed the doctrine of the dominant as a working principle of nerve centers. Due to the research, S. P. Botkin and I. P. Pavlov formulated the concept of nervousness, which proved the role of the nervous system in the regulation of physiological processes in the body. The study of the nervous system influence on the vital functions of the organism became a traditional direction of the Soviet Physiology (Sorokina, 2012, pp. 52-54).

Professor I. P. Pavlov made a special contribution to the Domestic Physiology formation, established the digestive glands activity patterns, the nervous regulation mechanism, the digestive juices formation dynamics. The Professor revealed the conditioned reflexes mechanisms of formation and inhibition. Furthermore, I. P. Pavlov founded a well-known scientific school, which developed the basic issues of human and Animal Physiology. Hence, L. O. Orbeli established the trophic influence of the nervous system, developed the adaptivetrophic theory of the sympathetic innervation, and laid the foundation of the evolutionary Physiology. One more researcher, K. M. Bykov found out the brain's large hemispheres influence on the organs functionality, the conditioned reflexes formation from the interceptors. V. V. Parin contributed to the introduction of Mathematics, Cybernetics, Radio Electronics in the study of Physiology (Zagrina, 2009, pp. 49-50).

The General Physiology evolved in the Ukrainian lands in $1805-1861$, when it became a disciplinary science, the first specialized departments were opened at the Natural Sciences and Medicine Faculties. Hence, the subject Physiology as part of the Natural Sciences and Botany general course began in 1819 at Kharkiv University Natural Sciences Faculty, which was later called "The Three Kingdoms of Nature Review". F. O. Delyavin, Würzburg and Erlangen Universities graduate, a Frenchman by origin, was invited to conduct the subject. As time passed by, Professor V. M. Chernyaev, the famous botanist taught Physiology from 1826 
to 1844 . During 1844 - 1857, Doctor of Zoology O. V. Cherkas taught a course in Comparative Anatomy, in which he presented material on Physiology. In 1857 the Comparative Anatomy and Animals Physiology singled out as the independent course from Zoology, which was taught by the talented scientist O. F. Maslovskyi (Shvalb, Ghlybycjka \& Stavnycjka, 2007, pp. 44-48).

At Kharkiv University Medical Faculty, the students took a course in "Anatomy, Physiology, Forensic Medicine and Medical Police". In 1805 the Human Anatomy and Physiology Department was opened, and L. Y. Vannoti made considerable efforts to establish it. His successor, I. D. Knyhin was a student at Moscow University and Medical and Surgical School at Moscow Land Hospital. Since 1829, Professor O. S. Venedyktov conducted the course, and then I. F. Leonov taught the course. The longest period, up to 1863, the course of Physiology, combined with General Pathology, was read by Professor I. Y. Kalenychenko. The Professor tried to introduce laboratory classes in Physiology (Bagalei, 1906, pp. 56-62). The Farm Animals Physiology Department at Kharkiv Veterinary Institute played an important role in the formation of Kharkiv Center for the Physiology Development. In 1851, Professor H. A. Palyuta taught a course in Zoophysiology.

Due to the Medical Faculty organization at the University of Kyiv in 1834, an equally progressive scientific center for the Physiology Development was formed. From 1842, lectures on Human Physiology were given by Professor E. E. Miram, while Anatomy course was lectured by Professor O. P. Walter. In particular, Professor O. P. Walter studied the effect of temperature on the activity of internal organs and systems of both warm-blooded and coldblooded animals (Vladimirskii-Budanov, 1884, pp. 48-49).

Hence, the emergence of General Physiology in the Ukrainian lands took place during 1805 - 1861. Initially, General Physiology took shape as a disciplinary science, the first specialized departments were opened at Kharkiv and Kyiv universities Natural Sciences and Medicine Faculties. During the 50-ies of the XIXth century, General Physiology branched out the Farm Animals Physiology as an independent science. The founders of General Physiology in the Ukrainian lands include the following professors: O. P. Walter, O. S. Venedyktov, I. F. Leonov, E. E. Miram, V. M. Chernyaev, and others.

During the following period, which covered 1861 - 1917, Kharkiv, Kyiv, and Odesa General Physiology development centers in the Ukrainian lands functioned. It should be noted that Kharkiv University scientists made a significant contribution to the Physiology scientific foundations development. Since 1884, Professor I. P. Shchelkov taught the Physiology course at the Natural Sciences Faculty entrusted to. Two years later the talented scientist headed the Physiology Department at the Medicine Faculty until 1886. For the first time, the Professor established the qualitative originality of gas exchange of tetanized muscles (Bulankin, 1955, pp. 47-48). Furthermore, the Professor described the role of carbohydrates in muscle contraction. Spectrographically investigated the quantitative difference between the content of hemoglobin in the blood of man and horse, this discovery became significant for the Evolutionary Physiology. He created a physiological research laboratory, introduced the systematic laboratory classes, and prepared a textbook on Physiology, the first issue of which in 1871 was devoted to the Physiology of the nervous system. In addition, Professor I. P. Shchelkov prepared numerous students, the most prominent of whom were: zoologist and pathophysiologist, founder of the phagocytic theory of immunity I. I. Mechnikov, physiologist V. Y. Danylevskyi, comparative physiologist M. F. Biletskyi, hematologist S. P. Alferov, and the others. In particular, M. F. Biletskyi became one of the founders of Domestic Comparative Physiology. In his fundamental monograph "Physiology of the Fish Air Bladder" (1883) Professor I. P. Shchelkov 
set out the provisions on the gases composition of the closed and open gas bladders considering different species of fish, the nature of the gas exchange between the bladder and blood (Shvalb, Ghlybycjka \& Stavnycjka, 2007, pp. 88-89).

During 1882 - 1887, one of the most prominent domestic physiologists, biologists, and antistologists, V. Ya. Danylevskyi, taught a course in Physiology. The renowned scientist developed the following problems: 1) the higher parts of the brain nervous system physiology; 2) the muscular activity physiology; 3) humoral regulation of life processes; 4) blood parasites. One of the outstanding works of that time was his monograph called "Studies in the Physiology of the Brain" (1876). Based on experimental facts, he put forward a position on the leading role of the cerebral cortex in the regulation of the autonomic functions of higher animals and humans. V. Ya. Danylevskyi left significant developments concerning the Peripheral Nervous System and Electrophysiology functioning. V. Ya. Danylevskyi studied the summation phenomenon of the electrical excitations occurring in the vagus nerve thoroughly. In addition, the researcher studied the effect of chemical stimuli on the peripheral nervous system. Moreover, V. Ya. Danilevskyi's Electrophysiological Studies are crucial, as the fluctuations of the electrical potential of the cerebral cortex in dogs were discovered, which occurred when its functional state changed. In essence, his discovery laid the foundations of modern Electroencephalography. V. Ya. Danylevskyi paid considerable attention to the study of the physiological action of the electromagnetic field, the influence of diathermic currents. V. Ya. Danylevsky's research on labor physiology is original (State archive of Kharkiv region, f. 928 , d. 2, c. 32, pp. 44-46). The search in the field of humoral regulators of life processes was indicative of the scientist. He developed a method for obtaining the protein-free alcoholwater extracts from the endocrine organs. V. Ya. Danylevskyi is the pathogenic protozoa doctrine founder, which can be found in the blood and hematopoietic organs. Moreover, the scientist developed the basics of humans and birds protozoa combating. The above-mentioned block of works took the world by the storm and brought him worldwide recognition. V. Ya. Danylevskyi founded the first specialized journal in Russia, which was called "Physiological Collection" (1888). The researcher published the textbook under the following title "Human Physiology" (1913), written in 2 volumes, in which he taught this field of knowledge not as an appendix to medicine, but as one of the most important biological sciences (SAKhR, f. 928, d. 3, c. 101, pp. 1-2).

As V. Ya. Danylevskyi became the Physiology Department Head at the Medical Faculty, the Nature Sciences Department of Physics and Mathematics Faculty at the university lost the Human and Animal Physiology laboratory. In addition, 1894 is considered to be the new period, when the laboratory was headed by M. F. Byelousov. He studied the sea anemones neuromuscular apparatus and the digestive system. In 1911 M. F. Byelousov managed to create the mechanical workshops at the department (Bagalei, 1906, pp. 124-126).

It should be highlighted that the Farm Animal Physiology Department at Kharkiv Veterinary Institute was crucial for the development of Physiology in Kharkiv. Professor H. A. Palyuta carried on conducting the Zoophysiology course from 1851 to 1879 . One more peculiar feature was that the department was headed jointly by diverse prominent figures. For instance, Professor V.Ya. Danylevskyi shared responsibilities with Professor H. A. Palyuta from 1870 to 1882 and Professor M. V. Ryazantsev headed jointly the department from 1895, who for the first time made an isolated ventricle of rennet in ruminants and determined the acidity of the rennet juice, established its digestive power and explored the rennet secretion continuity (SAKhR, f. R-1773, d. 11, pp. 45-48; SAKhR, f. 928, d. 1, c. 22, pp. 12-16). 
Consequently, the physiological research intensified at the University of Kyiv. From 1865 to 1883 the department was headed by Professor V. B. Tomsa, who was the experimental physiology basics developer. The Professor left original works on the physiology of lymphatic vessels, lymph formation, on the innervation of the skin and blood capillaries, the physiology of the nucleus of the sympathetic nerve cell, on blood circulation in the skin, on the anatomy and physiology of the skin. Furthermore, Professor V. B. Tomsa had talented students: P. F. Sukhanov, O. L. Rava, M. O. Rohovich and others. In 1884 the department was headed by Professor S. I. Chyryev, Professor I. M. Sechenov's former student. His research activities focused on the study of the electrical phenomena in nervous and muscular tissues, histology and physiology of the central nervous system and the physiology of the senses, the physiology of the cycle. Professor S. I. Chyryev was one of the first, who described sensitive nerve endings. In 1899 he published a textbook, which was called "Human Physiology" (Vladimirskii-Budanov, 1884, pp. 186-190). His successor at the department was a talented scientist, Professor V. Yu. Chahovets. V. Yu. Chahovets studied the mechanisms of bioelectric potentials formation, nerves and muscles irritation by electric current. The Professor made the first attempt to explain the biological potentials, developed the physicochemical basis of modern Electrophysiology. Professor V. Yu. Chahovets gained world fame as an electrophysiologist, who was called the "Russian Helmholtz". Due to his efforts, the physiological laboratory at the University of Kyiv became one of the best in the Russian Empire. At that time, a private associate professor of the University I. V. Belhovskyi developed a method of forming a small ventricle from the abomasum of calves, which was of great scientific interest for Zootechnical Physiology.

Professor O. V. Leontovych, who worked at Professor's S. I. Chyryev Physiology Department, made a significant contribution to the development of physiological research in Kyiv. For the first time, O. V. Leontovych established a double innervation of the skin with the cerebrospinal and autonomic (sympathetic) nerve fibers, which was established in other organs. As a result, the principle of double innervation discovery became important in modern Physiology. O. V. Leontovych headed the Physiology Department at Kyiv Polytechnic Institute until 1913 (Zhmudsjkyi, 1959, pp. 168-172).

Novorossiysk University was opened in 1865 as the third scientific center that played an important role in the General Physiology development in the Ukrainian lands. Initially, there was not any independent Physiology Department, hence, Doctor of Medical Sciences N. O. Bernshtein taught this discipline. The scientist studied the regulation of heat in the body, the mechanism of activity of the pulmonary-gastric nerve. Moreover, Bernshtein prepared a guide to Special Physiology (Bernshtein, 1868). In 1870, the Experimental Physiology Department was organized, and renowned Professor I. M. Syechenov was approved as its head. He continued to develop physiology issues in the following areas: the blood gases, nervous system and psychophysiology physiology. Professor I. M. Syechenov obtained important data on the respiratory function of the blood, in particular, proved that erythrocytes carry not only oxygen but also carbon dioxide from the tissues to the lungs. The Professor was the first, who discovered the carbhemoglobin, showed that the chemical bond between hemoglobin and carbon dioxide is weaker than its bond with oxygen, due to which the lungs rapidly displace carbon dioxide from this compound and replace it with oxygen. Professor I. M. Syechenov performed a number of studies on the nervous system physiology (Krichun, 1940, pp. 24-26). The next 40 years of research in physiology were headed by I. M. Syechenov's closest students, for example, P. A. Spiro, and from 1894 
B. F. Verigo, keeping the subject initiated by him. In addition, P. A. Spiro paid much attention to psychophysiological issues. In 1892, the physiological laboratory at the university organized the first laboratory of experimental psychology in the Russian Empire, which was headed by Professor M. M. Lange. B. F. Verigo became famous due to the cathodic depression phenomenon discovery. In adittion, B. F. Verigo paid considerable attention to general biological problems: heredity, sex, the cycle of matter and energy. Moreover, B. F. Verigo published two volumes of the textbook, which were called "Fundamentals of Human and Higher Animal Physiology” (1905, 1910) (Vasilev, 2010, pp. 310).

In 1914 Professor B. P. Babkin, I. P. Pavlov's former student, the author of the famous monograph "External Secretion of the Digestive Glands" was appointed the Physiology Department head. I. S. Beritov made a significant contribution to the formation of the laboratory, formalizing the law of conjugate irradiation of excitation in the central nervous system. Furthermore, the scientist carried out original studies of the reciprocal innervation of skeletal muscles, as well as the role of the refractory phase in the activity of neuromuscular drugs (Jurzhenko, 1968, pp. 238-242).

Hence, the period of $1861-1917$ is connected with the Kharkiv, Kyiv and Odesa scientific centers functioning, the Animal Physiology Departments opening at Veterinary and Agricultural Institutes, their material equipment and staff improvement. The decisive contribution was made by the following scientists: I. M. Syechenov, B. F. Verigo, I. P. Shchelkov, V. Ya. Danylevskyi, V. Yu. Chahovets, and others.

According to our research, the next period of the General Physiology development in the Ukrainian lands covered the 20-30-ies of the XXth century, was marked by the creation of new Physiology Departments and laboratories at universities, Pedagogical, Agricultural, Veterinary, Zootechnical and other institutes, as well as the organization of independent Physiology Research Institutes and large Physiological departments at some institutions. The Human and Animal Physiology Department at Kharkiv University carried on working activity, which until 1929 was headed by Professor M. F. Byelousov. Moreover, there was the division into the Physiology and Biological Chemistry Departments, which happened when Professor O. V. Nahornyi was at the head of the department. The scientist focused his efforts on the problems of aging and longevity. The Ontophysiology issue became the paramount one concerning the physiological research development at the university. As a result, Professor O. V. Nahornyi published fundamental monographs, for instance, "Life, Old Age and Death", written in 1923, "The Problem of Aging and Death", written in 1935, "The Problem of Aging and Longevity", written in 1940, which summarized the available factual material on the theory of aging and ontogenesis, determined the direction of further work in this area. Consequently, Professor O. V. Nahornyi and his students I. M. Bulankin, V. M. Nikitin, A. A. Rubanovska, I. D. Shumenko, V. I. Makhinko, R. I. Holubitska, H. P. Lytovchenko described the morphological, colloidchemical, biochemical and physiological changes of organisms in ontogenesis (Voroncov, Nikitin, Sjerkov, 1950, pp. 58-65).

Since 1926, the Human Physiology Department at Kharkiv Medical Institute was headed by I. P. Pavlov's one of the most talented students, G. W. Volborth. The prominent researcher studied the digestion physiology, created a new non-surgical technique for the formation of a double combined biliary fistula, studied the bile secretion and bile excretion stimuli. In addition, G. W. Volborth studied the stomach secretion and discovered the secretory effect of the sympathetic division of the autonomic nervous system. G. W. Volborth described the depletion phenomenon and body recovery process (Cyghanenko, Kryvonosov \& Kravchun, 
2002, pp. 220-228). Moreover, G. W. Volborth was awarded the I. P. Pavlova Prize, due to the achievements and published works, namely the collections, for instance, the "Exhaustion and Recovery Processes Physiology" (1941), "Fatigue and Recovery Processes Physiology" (1951), "Fatigue and Recovery Processes Physiology Issues" (1958). The study on the higher nervous activity and conditioned inhibition is considered to be the third area of G. W. Volborth's and his students' research (Lisovyi, 2010, pp. 152-156).

In 1926, V. Ya. Danylevskyi founded the Ukrainian Organ-Therapeutic Institute (the future Ukrainian Institute of Experimental Endocrinology), which became the leading center of endocrinological research in the USSR. In 1926, a Physiological Department was established, which was headed by Ye. K. Prykhod'kova, a corresponding member of the USSR Academy of Sciences. The Physiological Department's main tasks', at the head of Ye. K. Prykhod'kova was to clarify the pathophysiological basis of hypertension, physiologically normal spectrum of hormones for the nervous, cardiovascular and other body systems. E. M. Kahan, who headed the Occupational Physiology Laboratory at the Ukrainian Central Institute of Occupational Hygiene and Occupational Diseases, developed the Occupational Physiology issue. In addition to it, the scientist proved the possibility of applying energy methods to address the issues of rational construction of the labor process, establishing the sequence of work and rest alternation, the pace and rhythm of work.

The Physiology and Biochemistry Department was opened at Kharkiv Zootechnical Institute in 1925. It was headed by Professors J. V. Kronstadt, since 1930 by M. F. Byelousov, and since 1933 by V. M. Nikitin, a corresponding member of the USSR Academy of Sciences. Numerous issues were developed at the department, for instance, Age Zootechnical Physiology, digestion of ruminants and physiology and biochemistry of lactation issues. The Department of Physiology at the Kharkiv Veterinary Institute was headed by Professor M. G. Ponirovskyi. The Professor studied the coronary vessels of the heart innervation, the thyroid gland influence on the gastric juice and salivation secretion, the electrolytes importance in the occurrence and development of multiphase in the action of hormones and the nervous system in anaphylaxis. Professor M. G. Ponirovskyi brought in a method of studying the isolated heart innervation, deep organs and tissues electric stimulation, fistula method of obtaining sperm, etc (SAKhR, f. 928, d. 1, c. 1, pp. 12-14).

The Human and Animal Physiology issues were developed actively in Kyiv scientific centers. Professor V. Yu. Chahovets decided to change his place of work, as a result, he started working at Kyiv Medical Institute, which was organized on the basis of the Medical Faculty at the University of Kyiv. Professor V. Yu. Chahovets headed the Normal Physiology Department. However, his main work was connected with the Research Institute of Occupational Health and Occupational Diseases, where he headed the Electrophysiology Department. The Professor studied the skin-electrical reflexes, the action of currents on human skeletal muscles under different working conditions. Mechanical workshops were established at the institute, where galvanometers, Helmholtz pendulums and other physiological devices were manufactured. In $1939 \mathrm{~V}$. Yu. Chahovets was elected as a full member of the USSR Academy of Sciences (Goncharuk, 1991, pp. 164-168).

Since 1938 O. V. Leontovych worked at the Clinical Physiology Institute at the USSR Academy of Sciences, was a full member since 1929. The scientist studied the nervous system histophysiology, found out new facts about the blood vessels' innervation. Moreover, $\mathrm{O}$. V. Leontovych mastered the technique of working with a string galvanometer, developed his own method of making strings and conducted a number of studies in Electrocardiography. 
In 1916 O. V. Leontovych wrote an original textbook on the Farm Animals Physiology, which was republished four times. One more renowned figure was Professor O. A. Krontovskyi as he played an important role in Histophysiology development. From 1924 he headed the Biology and Experimental Medicine Department at the Kyiv X-ray Institute. In addition, Professor O. A. Krontovskyi studied the application of the tissue cultures method in endocrinology (Voroncov, Nikitin \& Sjerkov, 1959, pp. 118-121).

O. O. Bogomolets, one of the most prominent physiologists and pathophysiologists of Ukraine, the USSR Academy of Sciences President, Academician worked in Kyiv from 1930 to 1946. O. O. Bogomolets is the author of diverse outstanding works in the field of Age Physiology and Metabolism Pathophysiology and Endocrinology. In 1934 O. O. Bohomolets founded the Clinical Physiology Institute at the USSR Academy of Sciences. The starting point for the aging theory developed by the scientist is his idea of the exceptional importance concerning the connective tissue in the body (Stupak, 2002, pp. 68-72).

A. I. Yemchenko was f the Animal Physiology Department Head at the Biology Faculty at Kyiv University since 1932. The scientist studied the acids and salts effects on the heart, the digestion physiology, higher nervous activity. From 1935, the Human Physiology Department at Kyiv Medical Institute was headed by Professor D. S. Vorontsov. The Professor studied the physiological properties of motor nerve endings in skeletal muscles, in particular the phenomenon of pessimum. Numerous vital studies were conducted at Kyiv Veterinary Institute by Professor S. Yu. Yaroslav, in particular on the digestion physiology, blood circulation, lymph movement, breast physiology, electrocardiography (Borodai, 2012, pp. 80-81).

Furthermore, the above-mentioned period is characterized by an increase in the number of physiological departments and laboratories in Odesa. Hence, the Normal Physiology Department was organized at Odesa Medical Academy in 1920, which was later reorganized into a Medical Institute. The paramaount leaders were professors B. P. Babkin and A. M. Melik-Megrabov (since 1922), as well as scientists I. N. Sribner, H. S. Lurie, A. O. Voynar, V. E. Mayevskyi, M. A. Rosenberg made a significant contribution to its formation. During the 1920-ies, the basics of the respiration and blood circulation physiology were developed, and carried on the studies on immunity, which were instignated by B. F. Verigo (Verigo, 1896, pp. 199-200). The outcome is the received a number of new important facts about the characteristics of anaphylaxis and anaphylactic shock. In the 1930ies, along with the gas exchange studies, the functional changes in various body systems in sensitized animals were studied. Considerable attention was paid to the humoral changes establishment in the body during anaphylaxis, the conclusion was made about the special role of choline-like substances in the development of anaphylactic shock. Among other works of this period, it is necessary to note the research on the reflex regulation of a rhythm of the respiratory center, and also viscero-visceral reflexes. (Jurzhenko, 1968, pp. 288-296).

During the 1920-ies and 1930-ies, Physiology Departments and Physiological Laboratories were organized in Agricultural, Pharmaceutical, and Pedagogical Institutes, as well as in research institutes - Psychoneurological, Dental, Balneology, Tuberculosis, and eye diseases. Hence, Professor E. I. Synelnykov was the Physiology Department Head at Odesa Pharmaceutical Institute, and since 1937 this position took over R. J. Feitelberg. The scientists developed the digestive tract physiology and viscero-visceral reflexes issues. The Physiology Department at Odesa Agricultural Institute, established in 1930, was headed by L. A. Yegunov, and since 1932 by R. J. Feitelberg. On the basis of the Physiology Department 
at Odesa Agricultural Institute, a study on the Farm Animals Physiology was carried out. In addition, diverse issues were studied, for instance, the pleural receptors irritation effect on the activity of the salivary glands, stomach, liver and kidneys (Voroncov, Nikitin, \& Sjerkov, 1959, pp. 182-186).

The Physiology Department at Odessa Pedagogical Institute was organized in 1926. The scientist E. I. Synelnykov was in charge of its management until 1931, then R. J. Feitelberg. The department ceased its activity in 1938 due to the closure of the Biology Faculty (Central State Archives of Supreme Bodies of Power and Management of Ukraine, f. 166, d. 2. c. 454, pp. 12-14). The original researches were performed at Odesa Psychoneurological Institute. Professor E. I. Synelnykov was at the head of the Physiological Laboratory until 1934 and the viscero-visceral reflexes mechanisms were studied. It has been proven that the reflex interactions between the abdominal organs can occur without the spinal cord involvement. The sympathetic and vagus nerves effect on the vascular system of the brain was studied (Smyntyna, 2005, pp. 444-446). The above-mentioned experimental data formed the basis of the cerebrovascular dystonia doctrine created by the director of the institute, academician of the USSR Academy of Sciences, Professor H. I. Markelov. The influence of light and darkness on the functions of various organs was established (Jurzhenko, 1968, pp. 186-192).

The peculiarity of this period was that the research centers and educational institutions on Physiology were open in other regions of Ukraine. The Animal Physiology Department at Dnipropetrovsk Higher Institute of Public Education was founded in 1921. Professor V. M. Arkhanhelskyi was the first Head of the Animal Physiology Department, conducted research on the skin and motor analyzers physiology, studied the sex hormones effect on higher nervous activity in dogs. In 1936, with the support of Professor I. P. Pavlov, the Physiology Research Institute was opened at Dnipropetrovsk University, which studied mainly the physiological effects of the ultrahigh-frequency electric field. There were the following laboratories: Biophysics, Biochemistry, Histology and Animal Physiology. The influence of the ultrafrequency field on: the gas exchange (the research was conducted by P. M. Zubenko), the thyroid gland (G. T. Chukmasova studied the issue), the urination (T. M. Kozenko carried out the reseach), the reflex activity (D. O. Kocherha, G. Ya. Sych worked on the issue), the sympathetic nervous system (P. Ye. Motsnyi paid attention to the issue). One more researcher, B. O. Aleksenko studied morphological changes occurring under the influence of UHF in some endocrine glands.

In 1931, the Normal Physiology Department was organized at the Crimean Medical Institute. Until 1938, it was headed by T. T. Huryeyev, G. W. Volborth's a student. The scientist's research was aimed at studying the humoral effects on the secretion of gastric glands, the effect of afferent stimuli and the cerebral cortex on the salivation process. Since 1938, the department's staff research was carried out under Professor N. S. Spaskyi guidance and aimed at the further study of the physiology of the salivary glands, in particular, the hormones influence on the processes of absorption.

In 1931 Stalin (now Donetsk) Medical Institute Physiology Department was established, which was headed by V. Ya. Danylevskyi's and G. W. Volborth's students: M. M. Kudryavtsev, and then O. B. Feldman. The central inhibition was studied, as well as changes in the processes of excitation and inhibition under conditions of functional stress of the central nervous system, changes in cortical unconditional reflexes with repeated and prolonged stimuli. The Normal Physiology Department at Vinnytsya Medical Institute was established in 1934. The work was carried out on the physiological laboratory organization and its equipment. 
In addition, Poltava became an important center for the Zootechnical Physiology development, where the digestive problems physiology and reproductive system of farm animals were developed by the All-Union Research Institute of Pig Breeding and the Animal Physiology Department at Poltava Agricultural Institute headed by Academician O. V. Kvasnytskyi (Borodai, 2012, pp. 308-310). The All-Union Research Institute of Animal Hybridization and Acclimatization (Askania-Nova) made a significant contribution to the General and Zootechnical Physiology development. Professor I. I. Ivanov conducted the research on the animals' artificial insemination, the study of biological properties and biochemistry of sperm, the biochemistry of sperm. The scientist also studied the remote hybridization issues in order to understand the germ cells' biocompatibility of different species issues. The original studies were performed by Professor M. M. Zavadovskyi in the study of hormonal effects on the sexual characteristics development in animals (CDAVO, f. 4861, d. 1, c. 2009, pp. 8-12).

The Conclusions and Prospects for Further Research. Taking everything into consideration, the General Physiology formation in the Ukrainian lands happened due to the evolution of world biological science influence. During 1805 - 1861, the first Physiological Departments were established at national universities at the faculties of Natural and Medical Sciences, and General Physiology as a disciplinary science was formed thanks to the efforts of professors O. P. Walter, O. S. Venediktov, I. F. Leonov, and E. E. Mirama, V. M. Chernyaeva and others. In 1861 - 1917, Animal Physiology Departments were opened at Veterinary and Agricultural Institutes, and their material equipment and staffing were improved. The renowned scientists I. M. Syechenov and B. F. Verigo (Odesa), I. P. Shchelkov and V. Ya. Danylevskyi (Kharkiv), and V. Yu. Chahovets (Kyiv) made a decisive contribution to their formation. During the 1920-ies and 1930-ies, the Physiology Departments functioned at universities, Pedagogical, Agricultural, Veterinary, and Zootechnical Institutes. Numerous independent physiology research institutes were established (Bogomolets Institute of Physiology of the USSR Academy of Sciences, Institute of Physiology at Kyiv University, Institute of Experimental Endocrinology in Kharkiv, Institute of Physiology at Dnipropetrovsk University, etc.) as well as Physiological Departments at some scientific institutions in different regions of Ukraine, the methodological and theoretical bases of research programs were developed. The range of scientific fields expanded, although it remains uneven, duplicated in the subject of many scientific institutions and educational institutions. The most thoroughly developed issues were the nerves and muscles physiology, electrophysiology and biophysics, comparative and age physiology, endocrinology. Diverse issues concerning the analyzers physiology, brainstem, autonomic nervous system, respiration and excretion, thermoregulation, etc. were studied to some extent. The researchers S. Yu. Yaroslav and E. I. Synelnykov made a significant contribution to the circulatory and lymphatic systems physiology foundations development and the excretion processes; the scientists V. Ya. Danylevskyi and M. O. Rogovich provided vital data on Endocrinology; the Professors G. W. Volborth, A. M. Vorobyov, J. P. Sklyarov, A. I. Yemchenko, R. J. Feitelberg, T. T. Huryeyev found out the essential data concerning digestion. The higher nervous system physiology issues were studied by V. P. Prototypov; the autonomic nervous system G. P. Markelov; the analyzers - V. M. Arkhanhelskyi; nerves and muscles - D. S. Vorontsov, P. H. Kostyuk, P. M. Serkov. Biological science was enriched by research on the labour physiology, which was conducted by I. M. Syechenov, V. Ya. Danylevskyi, E. M. Kahan, V. M. Vasilevskyi. A new direction formed up: the Farm Animals Physiology. Consequently, A. V. Kvasnytskyi, V. M. Nikitin, Kh. T. Arskyi, and others made contribution to its formation. 
Acknowledgement. The author expresses gratitude to V. A. Verhunov, the National Scientific Agricultural Library Director at the National Academy of Agrarian Sciences of Ukraine for facilitating research.

Funding. The authors received no financial support for the research, authorship, and/or publication of this article.

\section{BIBLIOGRAPHY}

Bagaley, D. I. (1906). Kratkii ocherk istorii Kharkovskogo universiteta za pervye sto let ego sushchestvovaniia (1805-1905) [A brief outline of the history of Kharkov University in the first hundred years of its existence (1805-1905)]. Kharkiv, 329 p. [in Russian]

Bernstein, N. O. (1868). Rukovodstvo $k$ chastnoi fiziologii [A guide to Private Physiology]. Odessa, 312 p. [in Russian]

Bulankin, I. N. (1955). 150-letie Kharkovskogo universiteta [150th anniversary of Kharkov University]. Vestnik vysshei shkoly - High School Bulletin, 4, 46-51. [in Russian]

Borodai, I. S. (2012). Teoretyko-metodologhichni osnovy stanovlennja ta rozvytku vitchyznjanoji zootekhnichnoji nauky [Theoretical and methodological foundations of the domestic zootechnical science formation and development]. Vinnytsia, 416 p. [in Ukrainian]

Vasilev, Yu. K. (2010). Professor B. F. Verigo $(1860$ - 1825) v Odesse i ego deiatelnost v obshchestve Odesskikh vrachei [Professor B. F. Verigo $(1860-1825)$ in Odessa and his activities in the society of Odessa doctors]. Fiziologichnii zhurnal - Physiological journal, 56 (2), 310. [in Russian]

Verigo, B. F. (1896). Ob immunitete [On Immunity]. Yuzhno-russkaya meditsinskaya gazeta South-Russian medical newspaper, 17, 199-202. [in Russian]

Vladimirskyi-Budanov, M. F. (1884). Istoriia Imperatorskogo Universiteta Sviatogo Vladimira [St. Vladimir Imperial University History] (in 2 volumes, v.2). Kyiv, 598 p. [in Russian]

Vorontsov, D. S., Nikitin, V. M., \& Syerkov, P. M. (1959). Narysy z istoriji fiziologhiji na Ukrajini [Essays on the Physiology History in Ukraine]. Kyiv, 231 p. [in Ukrainian]

Holovko, V. O., Ruban, Yu. D., \& Kandyba, V. M. (ed. col.). (2006). Istorija Kharkivsjkoji derzhavnoji zooveterynarnoji akademiji. 155 rokiv [Kharkiv State Zooveterinary Academy History. 155 years]. Kharkiv, 496 p. [in Ukrainian]

Goncharuk, E. I. (ed.). (1991). 150 let Kievskomu meditcinskomu institutu [150 years of Kyiv Medical Institute]. Kyiv, 264 p. [in Russian]

Derzhavnyi arkhiv Kharkivskoi oblasti (SAKh $\boldsymbol{R}$ - State Archives of Kharkiv region)

Zhmudskyi, O. Z. (ed.) (1959). Istorija Kyjivsjkoho universytetu (1834 - 1959) [Kyiv University History (1834-1959)]. Kyiv, 629 p. [in Ukrainian]

Zagrina, N. A. (2009). Nauchno-pedagogicheskaia shkola akademika I. P. Pavlova [Academician I. P. Pavlov's Scientific and Pedagogical School]. Vestnik Rossiiskoi akademii meditcinskikh naukBulletin of the Russian Academy of Medical Sciences, 3, 48-52. [in Russian]

Kogan, A. B. (ed.). (1984). Fiziologiia cheloveka i zhivotnykh (obshchaia i evoliutcionnoekologicheskaia) [Humans and Animals Physiology (General and Evolutionary-ecological)] (in 2 hours, Part 1). Moscow, 359 p. [in Russian]

Krichun, A. V. (1940). Odesskii universitet v 1865 - 1899 gg. [Odessa University in $1865-1899$ ]. Odesskii universitet za 75 let (1865 - 1940) - Odessa University for 75 years (1865 - 1940) (pp. 5-48). Odessa. [in Russian]

Lisovyi, V. M. (ed.). (2010). Vydatni vykhovanci Kharkivsjkoji vyshhoji medychnoji shkoly: biblioghrafichnyj dovidnyk [Kharkiv Higher Medical School Outstanding Pupils: Bibliographic Reference]. Kharkiv, 208 p. [in Ukrainian]

Marynzha, L. (2011). V. Ja. Danylevskyj. Uchenyj bezmezhnykh upodobanj [V. Ya. Danylevskyi. A scientist of boundless tastes]. Istorija medycyny - History of Medicine, 15-16, 66-67. [in Ukrainian]

Samoilov, V. O. (2005). Illiustrirovannyi ocherk istorii fiziologii [Illustrated sketch on the History of Physiology]. St. Petersburg, 129 p. [in Russian] 
Smyntyna, V. A. (2005). Profesory Odeskoho (Novorosijskoho) universytetu: bioghrafichnyi slovnyk [Odessa (Novorossiysk) University Professors: Biographical Dictionary]. (in 4 volumes, vol. 4). (2nd type.). Odessa, 616 p. [in Ukrainian]

Sorokina, T. S. (2012). Lektcii po istorii fiziologii v Rossii (XIX-pervaia tret XX veka) [Lectures on the history of physiology in Russia (XIXth - first third of the XXth century)]. Moscow, $103 \mathrm{p}$. [in Ukrainian]

Stupak, F. Ya. (2002). Narys istoriji Nacionaljnogho medychnogho universytetu imeni O. O. Boghomoljcja [Essay on the history of the O. O. Bogomolets National Medical University]. Kyiv, $108 \mathrm{p}$. [in Ukrainian]

Tsentralnyi derzhavnyi arkhiv vyshchykh orhaniv vlady ta upravlinnia Ukrainy (CSTAHAAU Central State Archive of the highest authorities and administration of Ukraine)

Tsihanenko, A. Ya., Kryvonosov, M. V. \& Kravchun, P. H. (ed.). (2002). Vcheni Kharkivskoho derzhavnoho medychnoho universytetu, 1805 - 2005 [Kharkiv State Medical University Scientists, 1805 - 2005]. Kharkiv, 470 p. [in Ukrainian]

Schwalb, M. G., Hlybytska, S. B. \& Stavnytska, R. A. (ed.). (2007). Istorija Kharkivskoho universytetu 1804 - 2006 [Kharkiv University History 1804 - 2006] (in 3 volumes, Vol. 1). Kharkiv, 283 p. [in Ukrainian]

Yurzhenko, O. I. (ed.). (1968). Istorija Odeskoho universytetu za 100 rokiv (1865 - 1965) [Odessa University History for 100 years (1865 - 1965)]. Kyiv, 423 p. [in Ukrainian]

The article was received on January 09, 2020. Article recommended for publishing 26/08/2020. 